\title{
Revisiting the Male-Produced Aggregation Pheromone of the Lesser Mealworm, Alphitobius diaperinus (Coleoptera, Tenebrionidae): Identification of a Six-Component Pheromone from a Brazilian Population
}

\author{
Marla J. Hassemer, ${ }^{\dagger} \S, \#$ Josué Sant'Ana, ${ }^{\S}$ Miguel Borges, ${ }^{\#}$ David Withall, ${ }^{\Delta}$ John A. Pickett, ${ }^{\Delta}$

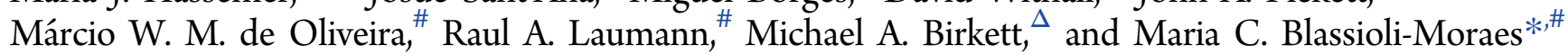 \\ ${ }^{\dagger}$ UnB - Universidade de Brasília, Departamento de Zoologia, Campus Universitário Darcy Ribeiro, Brasília, DF 70910-900, Brazil \\ ${ }^{\S}$ Universidade Federal do Rio Grande do Sul, PPG-Fitotecnia, Avenida Bento Gonçalves, 7712 Porto Alegre, RS 90040-060, Brazil \\ \#EMBRAPA Recursos Genéticos e Biotecnologia, Parque Estação Biológica, W5 Norte, 70770-917 Brasília, Brazil \\ ${ }^{\Delta}$ Biological Chemistry and Crop Protection Department, Rothamsted Research, Harpenden, Herts AL5 2JQ, United Kingdom \\ Supporting Information
}

ABSTRACT: The lesser mealworm, Alphitobius diaperinus Panzer 1797 (Coleoptera: Tenebrionidae), is a cosmopolitan insect pest affecting poultry production. Due to its cryptic behavior, insecticide control is usually not efficient. Thus, sustainable and effective methods would have an enormous and positive impact in poultry production. The aim of this study was to confirm the identity of the male-produced aggregation pheromone for a Brazilian population of $A$. diaperinus and to evaluate its biological activity in behavioral assays. Six male-specific compounds were identified: $(R)$-limonene (1), (E)-ocimene (2), 2-nonanone (3), $(S)$-linalool (4), (R)-daucene (5), all described before in an American population, and a sixth component, (E,E)- $\alpha$-farnesene (6), which is apparently exclusive to a Brazilian population. Y-Tube bioassays confirmed the presence of a male-produced aggregation pheromone and showed that all components need to be present in a similar ratio and concentration as emitted by male A. diaperinus to produce a positive chemotactic response.

KEYWORDS: Alphitobius diaperinus, aggregation pheromone, lesser mealworm

\section{INTRODUCTION}

The lesser mealworm, Alphitobius diaperinus Panzer 1797 (Coleoptera: Tenebrionidae), is a cosmopolitan insect pest affecting poultry production. ${ }^{1-3}$ Modern broiler facilities offer suitable environmental conditions for insect proliferation, including high temperatures, dark and sheltered sites, and moisture and food availability; consequently, high $A$. diaperinus larvae and adult densities are found, aggregating predominately under feeders and along house edges. ${ }^{4}-6$ Bacteria, viruses, and fungi can infect $A$. diaperinus at all stages of the life cycle, and so these insects are potential disease vectors affecting avine health. ${ }^{7-11}$ Control of $A$. diaperinus in poultry houses is currently undertaken using insecticide application, causing potential contamination of poultry and affecting meat quality. Additionally, due to the cryptic behavior of this pest, insecticide control is usually not efficient. Several studies have been conducted with the aim of developing alternative methods for lesser mealworm control, thereby minimizing reliance on the use of insecticides, ${ }^{12-14}$ including semiochemicals that modify A. diaperinus behavior. $^{15-18}$ A five component, male-produced aggregation pheromone for a North American population of A. diaperinus was reported. ${ }^{15}$ This pheromonal blend was tested in poultry houses, capturing more adults and larvae than control traps, ${ }^{15,16}$ indicating the effectiveness of these compounds in lesser mealworm management. In view of reported incidences of semiochemical diversity in geographically distinct insect populations, ${ }^{19-24}$ the aim of this study was to confirm the identity of the male-produced aggregation pheromone for a Brazilian population of $A$. diaperinus and to evaluate its biological activity in behavioral assays.

\section{MATERIALS AND METHODS}

Chemicals. Hexane for HPLC $(\geq 97 \%)$ and diethyl ether were purchased from Sigma-Aldrich and redistilled before use. (R)-Linalool (95\%) was purchased from Sigma-Aldrich (Steinheim, Germany), and $(R)$-limonene and $(S)$-limonene $(95 \%)$ were purchased from TCIAmerica (Portland, OR, USA). 2-Nonanone (99\%) was provided by Jeffrey R. Aldrich Consulting LLC (Santa Cruz, CA, USA). (E,E)- $\alpha$ Farnesene was synthesized in three steps from isoprene and sulfur dioxide by modifying the procedure reported by Spicer. ${ }^{25}$ Thus, sulfur dioxide $(30 \mathrm{~mL})$ was condensed into a pressure flask cooled to $-78{ }^{\circ} \mathrm{C}$ containing isoprene $(10 \mathrm{~g}, 146.80 \mathrm{mmol})$ and hydroquinone $(0.5 \mathrm{~g}$, $4.68 \mathrm{mmol}$ ) before being sealed and stirred for 7 days at room temperature. The reaction flask was cooled to $-78{ }^{\circ} \mathrm{C}$ and opened, allowing the sulfur dioxide to evaporate overnight in a fume hood. The residue was dissolved in methanol, filtered, and concentrated under vacuum. The crude material was recrystallized from hot methanol to provide 3 -methylsulfolene ( $13.7 \mathrm{~g}$, $71 \%$ yield) as a white crystalline solid. ${ }^{1} \mathrm{H}$ NMR $\left(\mathrm{CDCl}_{3}, 500 \mathrm{MHz}\right): \delta 5.70\left(\mathrm{~m}, 1 \mathrm{H}, \mathrm{SO}_{2} \mathrm{CH}_{2} \mathrm{CH}=\mathrm{C}\right)$, $3.81\left(\mathrm{~m}, 2 \mathrm{H}, \quad \mathrm{SO}_{2} \mathrm{CH}_{2}=\mathrm{C}\right), 3.69\left(\mathrm{~m}, 2 \mathrm{H}, \mathrm{SO}_{2} \mathrm{CH}_{2} \mathrm{C}\left(\mathrm{CH}_{3}\right)\right)$,

Received: May 17, 2016

Revised: July 18, 2016

Accepted: August 5, 2016

Published: August 5, 2016 
$1.90\left(\mathrm{~s}, 3 \mathrm{H}, \mathrm{CH}_{3}\right)$. To a solution of 3-methylsulfolene (1.32 g, $10.00 \mathrm{mmol})$ and geranyl bromide $(4.34 \mathrm{~g}, 20.00 \mathrm{mmol})$ in THF $(20 \mathrm{~mL})$, cooled to $-98{ }^{\circ} \mathrm{C}$ under $\mathrm{N}_{2}$, was added lithium bis(trimethylsilyl) amide $(1.67 \mathrm{~g}, 10.00 \mathrm{mmol})$ in THF $(7 \mathrm{~mL})$. The resulting solution was stirred for $10 \mathrm{~min}$ before being allowed to warm to room temperature over a further $30 \mathrm{~min}$. The reaction was quenched with saturated $\mathrm{NH}_{4} \mathrm{Cl}$ and the THF removed under vacuum. The residue was dissolved in EtOAc before being washed with water, dried $\left(\mathrm{MgSO}_{4}\right)$, and concentrated under vacuum. The crude product was purified on silica gel (20\% EtOAc in petroleum ether) to give the product $(514 \mathrm{mg}, 21 \%$ yield $)$ as a colorless oil. ${ }^{1} \mathrm{H} \mathrm{NMR}\left(\mathrm{CDCl}_{3}\right.$, $500 \mathrm{MHz}): \delta 5.70\left(\mathrm{~m}, 1 \mathrm{H}, \mathrm{SO}_{2} \mathrm{CH}_{2} \mathrm{CH}=\mathrm{C}\right), 5.24(\mathrm{~m}, 1 \mathrm{H}$, $\left.\left(\mathrm{CH}_{3}\right)_{2} \mathrm{C}=\mathrm{CHCH}_{2} \mathrm{CH}_{2} \mathrm{C}\left(\mathrm{CH}_{3}\right)=\mathrm{CH}\right), 5.09\left(\mathrm{~m}, 1 \mathrm{H},\left(\mathrm{CH}_{3}\right)_{2} \mathrm{C}=\right.$ $\mathrm{CH}), 3.69\left(\mathrm{~m}, 2 \mathrm{H}, \mathrm{SO}_{2} \mathrm{CH}_{2}\right), 3.53\left(\mathrm{~m}, 1 \mathrm{H}, \mathrm{SO}_{2} \mathrm{CH}\right), 2.59(\mathrm{~m}, 2 \mathrm{H}$, $\left.\left(\mathrm{CH}_{3}\right)_{2} \mathrm{C}=\mathrm{CHCH}_{2} \mathrm{CH}_{2} \mathrm{C}\left(\mathrm{CH}_{3}\right)=\mathrm{CHCH}_{2}\right), 2.12-2.03(\mathrm{~m}, 4 \mathrm{H}$, $\left.\left(\mathrm{CH}_{3}\right)_{2} \mathrm{C}=\mathrm{CHCH}_{2} \mathrm{CH}_{2}\right), 1.88\left(\mathrm{~s}, 3 \mathrm{H}, \mathrm{SO}_{2} \mathrm{CH}_{2} \mathrm{CH}=\mathrm{C}\left(\mathrm{CH}_{3}\right)\right), 1.69$ (s, 3H, $\left.\left(\mathrm{CH}_{3}\right)_{2} \mathrm{C}=\mathrm{CH}\right), 1.68\left(\mathrm{~s}, 3 \mathrm{H},\left(\mathrm{CH}_{3}\right)_{2} \mathrm{C}=\mathrm{CHCH}_{2} \mathrm{CH}_{2} \mathrm{C}\right.$ $\left.\left(\mathrm{CH}_{3}\right)=\mathrm{CH}\right), 1.62\left(\mathrm{~s}, 3 \mathrm{H},\left(\mathrm{CH}_{3}\right)_{2} \mathrm{C}=\mathrm{CH}\right)$. A solution of 2-(E-3,7dimethyl-2,6-octadiene)-3-methylsulfolene $(514 \mathrm{mg}, 2.02 \mathrm{mmol})$ in dry pyridine $(10 \mathrm{~mL})$ was heated to $150{ }^{\circ} \mathrm{C}$ under $\mathrm{N}_{2}$ for $3 \mathrm{~h}$. The reaction mixture was cooled, poured into $1 \mathrm{M} \mathrm{HCl}$, and extracted with petroleum ether. The combined organics were dried $\left(\mathrm{MgSO}_{4}\right)$ and concentrated under vacuum. The crude product was purified on florisil $(100 \%$ petroleum ether) to give $(E, E)-\alpha$-farnesene $(330 \mathrm{mg}, 80 \%)$ as a colorless oil $\left(>95 \%\right.$ pure by GC). ${ }^{1} \mathrm{H}$ NMR $\left(\mathrm{CDCl}_{3}, 500 \mathrm{MHz}\right)$ : $\delta 6.27\left(\mathrm{dd}, 1 \mathrm{H}, J=17.5,10.7 \mathrm{~Hz}, \mathrm{CH}_{2}=\mathrm{CH}\right), 5.49(\mathrm{t}, 1 \mathrm{H}, J=7.4 \mathrm{~Hz}$, $\left.\left.\mathrm{CH}_{2}=\mathrm{CHC}\left(\mathrm{CH}_{3}\right)=\mathrm{CH}\right)\right)$, 5.17-5.01 (m, 3H, $\left(\mathrm{CH}_{3}\right)_{2} \mathrm{C}=$ $\left.\mathrm{CHCH}_{2} \mathrm{CH}_{2} \mathrm{C}\left(\mathrm{CH}_{3}\right)=\mathrm{CHCH}_{2} \mathrm{CH}=\mathrm{C}\left(\mathrm{CH}_{3}\right) \mathrm{CH}=\mathrm{CH}_{2}\right), 4.96(\mathrm{~d}$, $\left.1 \mathrm{H}, J=10.6 \mathrm{~Hz}, \mathrm{CH}_{2}=\mathrm{CH}\right), 2.85\left(\mathrm{t}, 2 \mathrm{H}, J=7.2 \mathrm{~Hz},\left(\mathrm{CH}_{3}\right)_{2} \mathrm{C}=\right.$ $\left.\mathrm{CHCH}_{2} \mathrm{CH}_{2} \mathrm{C}\left(\mathrm{CH}_{3}\right)=\mathrm{CHCH}_{2}\right), 2.09\left(\mathrm{~m}, 2 \mathrm{H},\left(\mathrm{CH}_{3}\right)_{2} \mathrm{C}=\mathrm{CHCH}_{2}\right)$, $2.02\left(\mathrm{~m}, 2 \mathrm{H},\left(\mathrm{CH}_{3}\right)_{2} \mathrm{C}=\mathrm{CHCH}_{2} \mathrm{CH}_{2}\right), 1.79\left(\mathrm{~s}, 3 \mathrm{H}, \mathrm{CH}_{2}=\mathrm{CHC}-\right.$ $\left.\left(\mathrm{CH}_{3}\right)\right), 1.71\left(\mathrm{~s}, 3 \mathrm{H},\left(\mathrm{CH}_{3}\right)_{2} \mathrm{C}=\mathrm{CH}\right), 1.66\left(\mathrm{~s}, 3 \mathrm{H},\left(\mathrm{CH}_{3}\right)_{2} \mathrm{C}=\right.$ $\left.\mathrm{CHCH}_{2} \mathrm{CH}_{2} \mathrm{C}\left(\mathrm{CH}_{3}\right)\right), 1.63\left(\mathrm{~s}, 3 \mathrm{H},\left(\mathrm{CH}_{3}\right)_{2} \mathrm{C}=\mathrm{CH}\right)$. (R)-Daucene was synthesized from $(R)$-carotol obtained from carrot seeds. ${ }^{15,26,27}$ Carrot seeds $(15.6 \mathrm{~g})$ of the Brasília variety were extracted for $8 \mathrm{~h}$ in $n$-hexane at ambient temperature. The hexane extract was filtered and evaporated under vacuum to provide a pale yellow oil $(571.5 \mathrm{mg})$, which was subjected to liquid chromatography over silica gel (15 g, Sigma-Aldrich, $80 / 100 \mathrm{mesh})$. The oil $(250 \mathrm{mg})$ was eluted sequentially with hexane $(3 \times 10 \mathrm{~mL})$ and $98: 2$ diethyl ether/hexane $(10 \times 10 \mathrm{~mL})$. The carotol structure was confirmed by NMR and GC-MS analysis and was obtained in $98 \%$ purity (by GC analysis). ${ }^{1} \mathrm{H}$ NMR $\left(\mathrm{CDCl}_{3}, 500 \mathrm{MHz}\right): \delta 5.31\left(\mathrm{~m}, 1 \mathrm{H},\left(\mathrm{CH}_{3}\right) \mathrm{C}=\mathrm{CH}\right)$, $2.25\left(\mathrm{br} \mathrm{d}, 1 \mathrm{H}, \mathrm{J}=16 \mathrm{~Hz},\left(\mathrm{CH}_{3}\right) \mathrm{C}=\mathrm{CHCH}_{2}\right), 2.07(\mathrm{~m}, 2 \mathrm{H}$, $\left.\mathrm{CH}=\mathrm{C}\left(\mathrm{CH}_{3}\right) \mathrm{CH}_{2}\right), 1.94\left(\mathrm{~m}, 1 \mathrm{H}, \mathrm{CH}=\mathrm{C}\left(\mathrm{CH}_{3}\right) \mathrm{CH}_{2} \mathrm{CH}_{2}\right), 1.79$ $\left(\mathrm{m}, 2 \mathrm{H},\left(\mathrm{CH}_{3}\right)_{2} \mathrm{CHCH}\right), 1.72-1.47(\mathrm{~m}, 8 \mathrm{H}), 1.29(\mathrm{~m}, 1 \mathrm{H}$, $\left.\left(\mathrm{CH}_{3}\right)_{2} \mathrm{CHCHCH}_{2} \mathrm{CH}_{2}\right), 1.14$ (bs, $\left.1 \mathrm{H}, \mathrm{OH}\right), 0.99$ (d, $3 \mathrm{H}, \mathrm{J}=6.7 \mathrm{~Hz}$, $\left.\left(\mathrm{CH}_{3}\right)_{2} \mathrm{CH}\right), 0.94\left(\mathrm{~m}, 6 \mathrm{H},\left(\mathrm{CH}_{3}\right)_{2} \mathrm{CH}\right.$ and $\left.\mathrm{C}(\mathrm{OH}) \mathrm{C}\left(\mathrm{CH}_{3}\right)\right)$. $[\alpha]^{20}{ }_{\mathrm{D}}=+27.5\left(\mathrm{c} 0.76, \mathrm{CHCl}_{3}\right.$; literature $\left.[\alpha]_{\mathrm{D}}^{20}=+29.6\right){ }^{27}$ Carotol $(102.96 \mathrm{mg})$ was then treated with thionyl chloride in pyridine, ${ }^{27}$ with $(R)$-daucene $(82.32 \mathrm{mg})$ obtained in $87 \%$ purity (by GC analysis). ${ }^{1} \mathrm{H}$ NMR $\left(\mathrm{CDCl}_{3}, 500 \mathrm{MHz}\right): \delta 5.42\left(\mathrm{~m}, 1 \mathrm{H},\left(\mathrm{CH}_{3}\right) \mathrm{C}=\mathrm{CH}\right), 2.66$ (sept, $\left.1 \mathrm{H}, J=6.7 \mathrm{~Hz},\left(\mathrm{CH}_{3}\right)_{2} \mathrm{CH}\right), 2.39\left(\mathrm{~m}, 1 \mathrm{H},\left(\mathrm{CH}_{3}\right)_{2} \mathrm{CHCCH}_{2}\right)$, $2.16\left(\mathrm{~m}, 2 \mathrm{H}, \mathrm{CH}=\mathrm{C}\left(\mathrm{CH}_{3}\right) \mathrm{CH}_{2}\right), 2.07-1.92\left(\mathrm{~m}, 3 \mathrm{H},\left(\mathrm{CH}_{3}\right) \mathrm{C}=\right.$ $\mathrm{CHCH}_{2}$ and $\left.\left(\mathrm{CH}_{3}\right)_{2} \mathrm{CHCCH}_{2}\right), 1.82\left(\mathrm{~m}, 1 \mathrm{H}, \mathrm{CH}=\mathrm{C}\left(\mathrm{CH}_{3}\right)-\right.$ $\left.\mathrm{CH}_{2} \mathrm{CH}_{2}\right), 1.74\left(\mathrm{~s}, 3 \mathrm{H},\left(\mathrm{CH}_{3}\right) \mathrm{C}=\mathrm{CH}_{2}\right), 1.61-1.42(\mathrm{~m}, 3 \mathrm{H}, \mathrm{CH}=$ $\mathrm{C}\left(\mathrm{CH}_{3}\right) \mathrm{CH}_{2} \mathrm{CH}_{2}$ and $\left.\left(\mathrm{CH}_{3}\right)_{2} \mathrm{CHCCH}_{2} \mathrm{CH}_{2}\right), 0.97(\mathrm{~d}, 3 \mathrm{H}, J=6.7 \mathrm{~Hz}$, $\left.\left(\mathrm{CH}_{3}\right)_{2} \mathrm{CH}\right), 0.93\left(\mathrm{~d}, 3 \mathrm{H}, \mathrm{J}=6.7 \mathrm{~Hz},\left(\mathrm{CH}_{3}\right)_{2} \mathrm{CH}\right), 0.91\left(\mathrm{~s}, 3 \mathrm{H}, \mathrm{CH}_{3} \mathrm{C}\right)$. $[\alpha]_{\mathrm{D}}^{20}=+22.0\left(c \mathrm{c} 0.53, \mathrm{CHCl}_{3}\right.$; literature $(S)$-daucene $[\alpha]_{\mathrm{D}}^{20}=-24.9$, $\left.\mathrm{CHCl}_{3}\right){ }^{28}(S)$-Linalool was obtained from coriander seed essential oil. Thus, seeds of coriander, Coriandrum sativum L. (2.6 kg), were extracted by hydrodistillation providing a pale-colored oil (2.2 g). GC-FID analysis showed that the major component (85\%) was linalool. The oil $(0.6 \mathrm{~g})$ was subjected to liquid chromatography on silica gel (30 g, Sigma-Aldrich, 80/100 mesh) with sequential elution using petroleum ether $(5 \times 20 \mathrm{~mL})$ and 95:5 petroleum ether/ethyl acetate $(20 \times 20 \mathrm{~mL})$ to obtain linalool in $98 \%$ purity. The enantiomeric purity of the linalool obtained from the coriander seed oil was analyzed using a chiral $\beta$-DEX 325 column, as described above. The $(S)$ to $(R)$ ratio was determined to be $86: 14$ by GC. (E)-Ocimene was obtained in high purity from a commercially available sample of ocimene (Sigma-Aldrich) containing a 30:65 mix of $(Z)$ and $(E)$ isomers. A sample of the ocimene $(100 \mathrm{mg})$ was chromatographed on $0.5 \mathrm{~g}$ of $\mathrm{SiO}_{2}$ (Sigma-Aldrich, 80/100 mesh) impregnated with $25 \% \mathrm{AgNO}_{3}$ (Sigma-Aldrich, St. Louis, MO, USA), with elution using 97.5:2.5 hexane/diethyl ether $(15 \times 1 \mathrm{~mL})$. The ratio between both isomers was determined by GC-FID analysis using a DB-5MS column (30 m length, $0.25 \mathrm{~mm}$ i.d., $0.25 \mu \mathrm{m}$ film; Supelco, Bellefonte, PA, USA) and a splitless injector, with helium as the carrier gas. The oven temperature program began at $50{ }^{\circ} \mathrm{C}$ for $2 \mathrm{~min}$ and increased at $15{ }^{\circ} \mathrm{C} /$ min to $250{ }^{\circ} \mathrm{C}$, and then this temperature was maintained for $20 \mathrm{~min}$. (E)-Ocimene was obtained in $98 \%$ purity (by GC analysis) and (Z)-ocimene in $95 \%$ purity.

Insects. Adults of $A$. diaperinus were obtained from a commercial poultry farm in $\mathrm{PAD} / \mathrm{DF}$, Brasília, DF, Brazil $\left(15^{\circ} 59^{\prime} 40.5^{\prime \prime} \mathrm{S}\right.$ $\left.47^{\circ} 37^{\prime} 22.8^{\prime \prime} \mathrm{W}\right)$. The insects were reared at Embrapa Genetics Resources and Biotechnology, Brasília, DF, Brazil $\left(15^{\circ} 43^{\prime} 48.0^{\prime \prime} \mathrm{S}\right.$ $\left.47^{\circ} 53^{\prime} 59.5^{\prime \prime} \mathrm{W}\right)$ in plastic boxes $(40 \times 20 \mathrm{~cm})$ containing a fine layer of wood shavings and corrugated cardboard on top. ${ }^{29}$ Adults and larvae were fed with a commercial chicken feed three times a week (composition: ground corn, soybeans, wheat, rice meal, meat meal, limestone, salt, vitamin premix, probiotics, and minerals) and were provided with water daily. Boxes were kept in an environmentally controlled room $\left[\left(27 \pm 2{ }^{\circ} \mathrm{C}, 60-80 \%\right.\right.$ relative humidity $(\mathrm{RH})$, and 16:8 h (D/L) photoperiod]. For bioassays and volatile collections, pupae were separated by sex and placed in new boxes. The genders were distinguished by differences in pupal abdominal appendages. $^{30}$

Semiochemical Collection. Two hundred 10-day-old virgin male and female beetles were placed separately in glass chambers $(500 \mathrm{~mL})$, containing a fine layer of vermiculite (approximately $1 \mathrm{~cm}$ ) and a steel mesh $(4 \times 10 \mathrm{~cm})$, that were used as shelter. Humidified and purified air (charcoal filter 20-40 mesh) was drawn through the flasks at $300 \mathrm{~mL} / \mathrm{min}$ using a vacuum pump. Volatiles from the insects were trapped every $24 \mathrm{~h}$ using porous polymer adsorbent $(100 \mathrm{mg}$ of Porapak-Q 60-80 mesh, Sigma-Aldrich). To avoid contaminants, volatile collections were conducted without food. To guarantee insects were well fed during collections and minimize release of defense compounds, ${ }^{15,18}$ each group of 200 insects was replaced every day. Individuals that died were replaced. Volatile collections were performed consecutively for 60 days, and the trapped volatiles were eluted from adsorbent using $500 \mu \mathrm{L}$ of $n$-hexane and concentrated to $100 \mu \mathrm{L}$ under a gentle flow of $\mathrm{N}_{2}$. The samples were stored at $-20{ }^{\circ} \mathrm{C}$ until use. The volatiles from the fine layer of vermiculite (approximately $1 \mathrm{~cm})$ and a steel mesh $(4 \times 10 \mathrm{~cm})($ control) were also collected during consecutive 60 days to check for possible contaminants.

Olfactometry. Behavioral bioassays were conducted using a Y-olfactometer manufactured in a square acrylic block $(26.0 \times 23.0 \mathrm{~cm})$ with a Y-shaped cavity $(1.5 \mathrm{~cm}$ thickness $)$ sandwiched between two glass plates. The apparatus trunk measured $12.0 \mathrm{~cm}$, and each arm measured $10.5 \mathrm{~cm}$ in length. ${ }^{31}$ Bioassays were carried out in a controlled environment room at $25 \pm 1{ }^{\circ} \mathrm{C}$ and $60 \pm 10 \% \mathrm{RH}$, on a white bench under red artificial lighting $(514 \mathrm{~lx})$. Charcoal-filtered and humidified air was pushed into the system at $0.6 \mathrm{~L} / \mathrm{min}$ and pulled out at $0.3 \mathrm{~L} / \mathrm{min}$. This "push-pull" system prevents entry of contaminating volatiles from the exterior. A single virgin $A$. diaperinus (15 days old) was introduced individually at the olfactometer trunk base and observed for $300 \mathrm{~s}$. Both sexes were assayed at the same time in two olfactometer sets, until a total of 40 males and 40 females had responded. If no choice was made in $4 \mathrm{~min}$, the bioassay was aborted and the insect recorded as nonresponding. ${ }^{32}$ The following observations were recorded: (1) first choice, considered when beetles entered $2.0 \mathrm{~cm}$ into the arm; (2) residence time, measured as the mean of total bioassay time spent in each arm of the olfactometer. Each individual was sampled only once, and the filter papers were replaced after every five repetitions. At this time the Y-olfactometer was exchanged and cleaned with detergent, distilled water, and acetone. Silicone tubing, filter papers, and glass syringes were baked in an oven for at least $12 \mathrm{~h}$ at $45{ }^{\circ} \mathrm{C}$ prior to use. In the first experiment, 


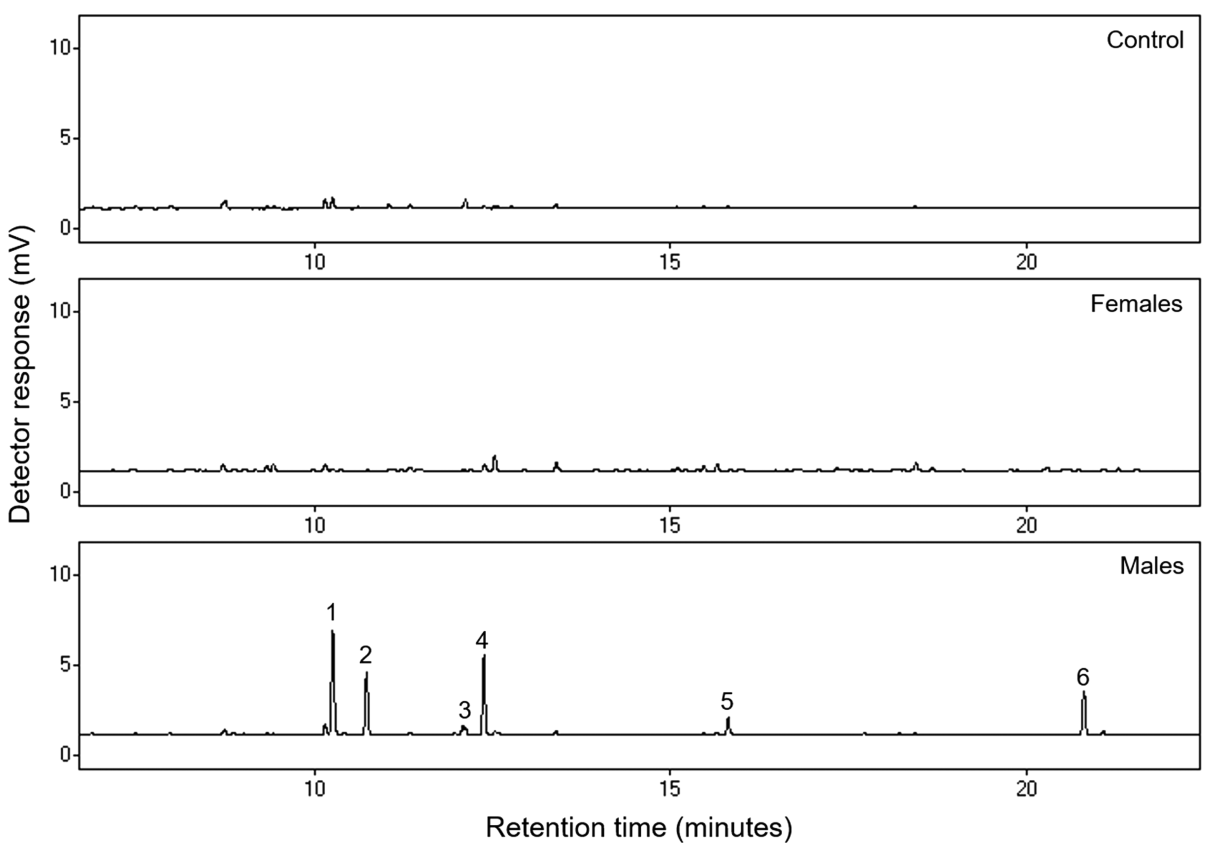

Figure 1. Gas chromatograms of volatile collections of glass chambers containing vermiculite (control), Alphitobius diaperinus females plus vermiculite, and $A$. diaperinus males plus vermiculite. Peaks: 1, $(R)$-limonene; 2, $(E)$-ocimene; 3, 2-nonanone; 4, $(S)$-linalool; 5, $(R)$-daucene; $6,(E, E)-\alpha$-farnesene.

the chemotaxis behavior of $A$. diaperinus toward the odor of live conspecifics was assessed. Each olfactometer arm was connected to a $20 \mathrm{~mL}$ glass syringe containing either 20 virgin sexually mature females, 20 virgin sexually mature males, 10 of each sex, or air (control). The insects in the syringe were allowed to acclimatize for $30 \mathrm{~min}$ before experiments started and were replaced after every 10 repetitions. In the second experiment, the chemotaxis behavior of A. diaperinus toward collected male volatiles, synthetic solutions, or hexane (control) was recorded. The following treatments were evaluated as odor stimuli: male extract at a concentration of 1 insect equivalent $/ \mu \mathrm{L}(\mathrm{IE} / \mu \mathrm{L})$ and synthetic solution (SS) containing all compounds produced by males at $0.1,1$, and $10 \mathrm{IE} / \mu \mathrm{L}[(R)$-limonene, $(E)$-ocimene, 2-nonanone, $(S)$-linalool, $(R)$-daucene, and $(E, E)-\alpha$ farnesene)]. Each olfactometer arm was connected to a $10 \mathrm{~mL}$ glass syringe containing a filter paper $(0.5 \mathrm{~cm}$ width, $1.0 \mathrm{~cm}$ length, $205 \mu \mathrm{m}$ thicknesses) treated with $10 \mu \mathrm{L}$ of each treatment. To determine whether all compounds were necessary to modify $A$. diaperinus behavior, a third experiment was conducted using synthetic solutions missing one of the identified components. A fourth experiment was undertaken to evaluate the influence of non-naturally occurring isomers, and for this, four different blends containing the six components (mix), with one of the components present as a different isomer, were evaluated. The isomers evaluated were $(S)$-limonene, $(Z)$-ocimene, $(R)$-linalool, and a mixture of farnesene isomers. $(S)$-Daucene was not tested because it was unavailable.

Chemical Analyses. GC-FID analyses of collected volatile extracts were performed using a gas chromatograph (Shimadzu 17A) equipped with a DB-5MS column ( $30 \mathrm{~m}$ length, $0.25 \mathrm{~mm}$ i.d., $0.25 \mu \mathrm{m}$ film thickness; Supelco). The carrier gas was helium. The oven temperature program was programmed to start at $50{ }^{\circ} \mathrm{C}$ for $2 \mathrm{~min}$, increase at $5{ }^{\circ} \mathrm{C} / \mathrm{min}$ to $180{ }^{\circ} \mathrm{C}$, and then increase at $10{ }^{\circ} \mathrm{C} / \mathrm{min}$ to $250{ }^{\circ} \mathrm{C}$, with the final hold time of $20 \mathrm{~min}$. One microliter of each selected sample was injected in splitless mode; the injector temperature was $250{ }^{\circ} \mathrm{C}$, and the detector temperature was $270^{\circ} \mathrm{C}$. Compounds were quantified by comparing GC peak areas with the peak area of the internal standard (IS) ( $n$-tetracosane; IS was prepared at a final concentration of $1 \mu \mathrm{g} / \mathrm{mL})$.

For qualitative analysis, selected volatile extracts were analyzed by coupled GC-MS using an Agilent MSD 5975C quadrupole mass spectrometer coupled to a gas chromatograph (GC-MS Agilent, 7890A) equipped with a DB-5 column ( $30 \mathrm{~m}$ length, $0.25 \mathrm{~mm}$ i.d., $0.25 \mu \mathrm{m}$ thickness
Table 1. Mean Quantity \pm Standard Error (SE) and Retention Index of Each Male Specific Compound Using DB-5MS and DB-WAX GC Columns

\begin{tabular}{lccc} 
& & \multicolumn{2}{c}{ retention index on } \\
\cline { 3 - 4 } \multicolumn{1}{c}{ compound } & quantity \pm SE $(\mathrm{ng} /$ insect/day $)$ & DB-5MS & DB-WAX \\
(R)-limonene & $49.0 \pm 10.4$ & 1030 & 1188 \\
$(E)$-ocimene & $31.3 \pm 6.9$ & 1050 & 1249 \\
2-nonanone & $7.0 \pm 1.4$ & 1091 & 1386 \\
$(S)$-linalool & $50.0 \pm 12.9$ & 1103 & 1551 \\
$(R)$-daucene & $18.4 \pm 1.2$ & 1378 & 1487 \\
$(E, E)$ - $\alpha$-farnesene & $44.5 \pm 10.8$ & 1508 & 1735 \\
\hline
\end{tabular}

film; Supelco) and a splitless injector, with helium as the carrier gas, using the same temperature program described for GC-FID analysis. Ionization was performed by electron impact $(70 \mathrm{eV}$; source temperature = $200{ }^{\circ} \mathrm{C}$ ). Data were collected using ChemStation software (Agilent Technologies). Tentative identifications were made by comparison of the target spectra with library databases (NIST and Wiley 2008), with published spectra and the retention indices (RI). ${ }^{33,34}$ Confirmation of the identifications was done by GC peak enhancement with authentic standards. The absolute configuration of limonene and linalool produced by males was determined by enantioselective gas chromatography using a chiral GC column $(30 \mathrm{~mm} \times 0.25 \mathrm{~mm}$ i.d., $0.25 \mu \mathrm{m}, \beta$-DEX 325 matrix nonbonded with $25 \%$ 2,3-di- $O$-acetyl-6-O-TBDMS- $\beta$-cyclodextrin in SPB- 20 poly $(20 \%$ phenyl $/ 80 \%$ dimethylsiloxane phase) (Supelco, USA). The oven temperature was programmed as follows: $50{ }^{\circ} \mathrm{C}$ for $2 \mathrm{~min}$, increase at $2{ }^{\circ} \mathrm{C} / \mathrm{min}$ until $210^{\circ} \mathrm{C}$, and hold for $10 \mathrm{~min}$. Injections were made in splitless mode with helium as the carrier gas $(1.5 \mathrm{~mL} / \mathrm{min})$, injector temperature at $250{ }^{\circ} \mathrm{C}$, and detector temperature at $270{ }^{\circ} \mathrm{C}$. To confirm the identity of $(E, E)-\alpha$-farnesene, male volatile extracts and authentic standards were also analyzed and co-injected using a DB-WAX column ( $30 \mathrm{~m}$ length, $0.25 \mathrm{~mm}$ i.d., $1.0 \mu \mathrm{m}$ film thickness; Supelco). The carrier gas was helium. The oven temperature program began at $50{ }^{\circ} \mathrm{C}$ for $2 \mathrm{~min}$, increased at $5{ }^{\circ} \mathrm{C} / \mathrm{min}$ to $180^{\circ} \mathrm{C}$, and then increased at $10{ }^{\circ} \mathrm{C} / \mathrm{min}$ to $250{ }^{\circ} \mathrm{C}$; this temperature was maintained for $20 \mathrm{~min}$. One microliter of each selected sample was injected in splitless mode; the injector temperature was $250{ }^{\circ} \mathrm{C}$, and the detector temperature was $270{ }^{\circ} \mathrm{C}$ 


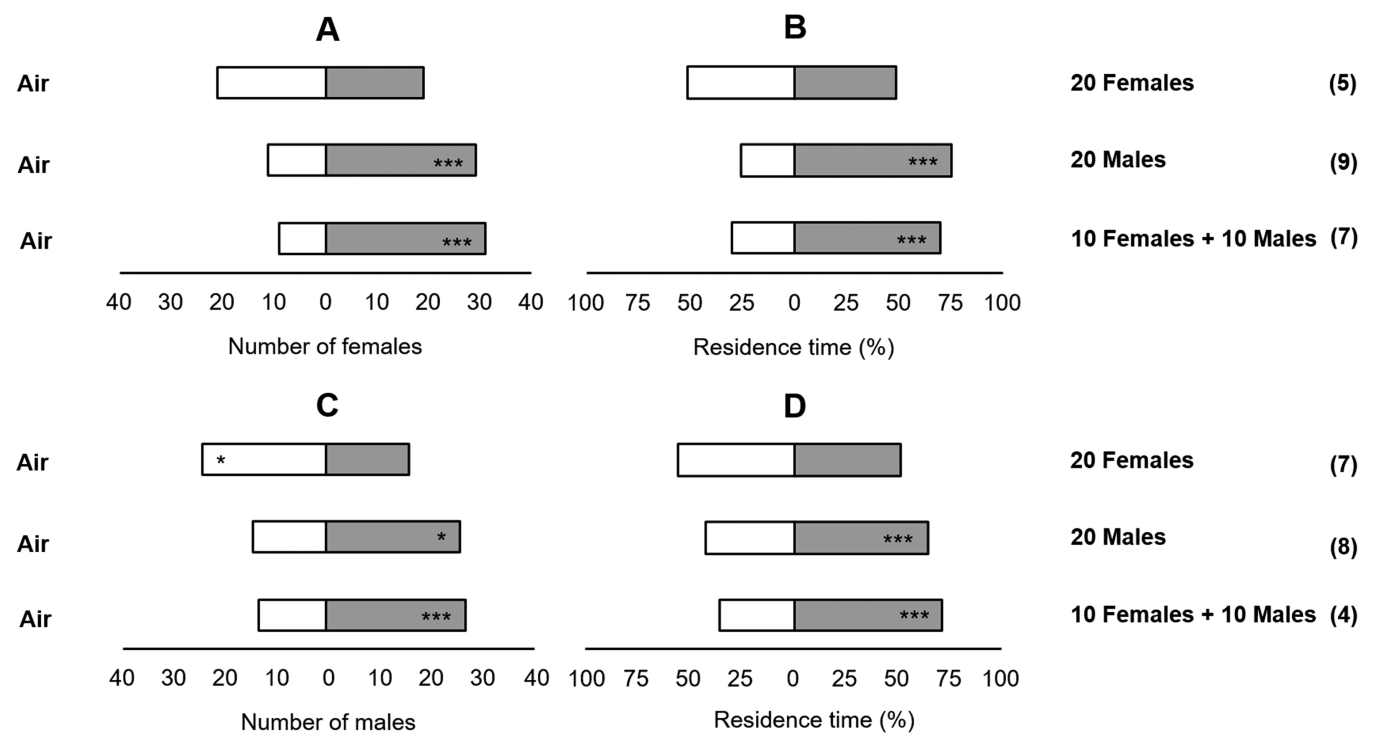

Figure 2. First choice and residence time of female (A, B) and male (C, D) Alphitobius diaperinus in Y-tube olfactometer bioassays with the odor of live insects against air as control. Analyses were carried out using chi-square test for first choice and Wilcoxon's matched-pairs test for residence time. Bars indicate the number of responsive insects and the residence time (\%) to each olfactometer arm. $*, P<0.05 ; * * *, P<0.001$. Numbers in parentheses represent the number of insects that did not respond to the treatment tested.

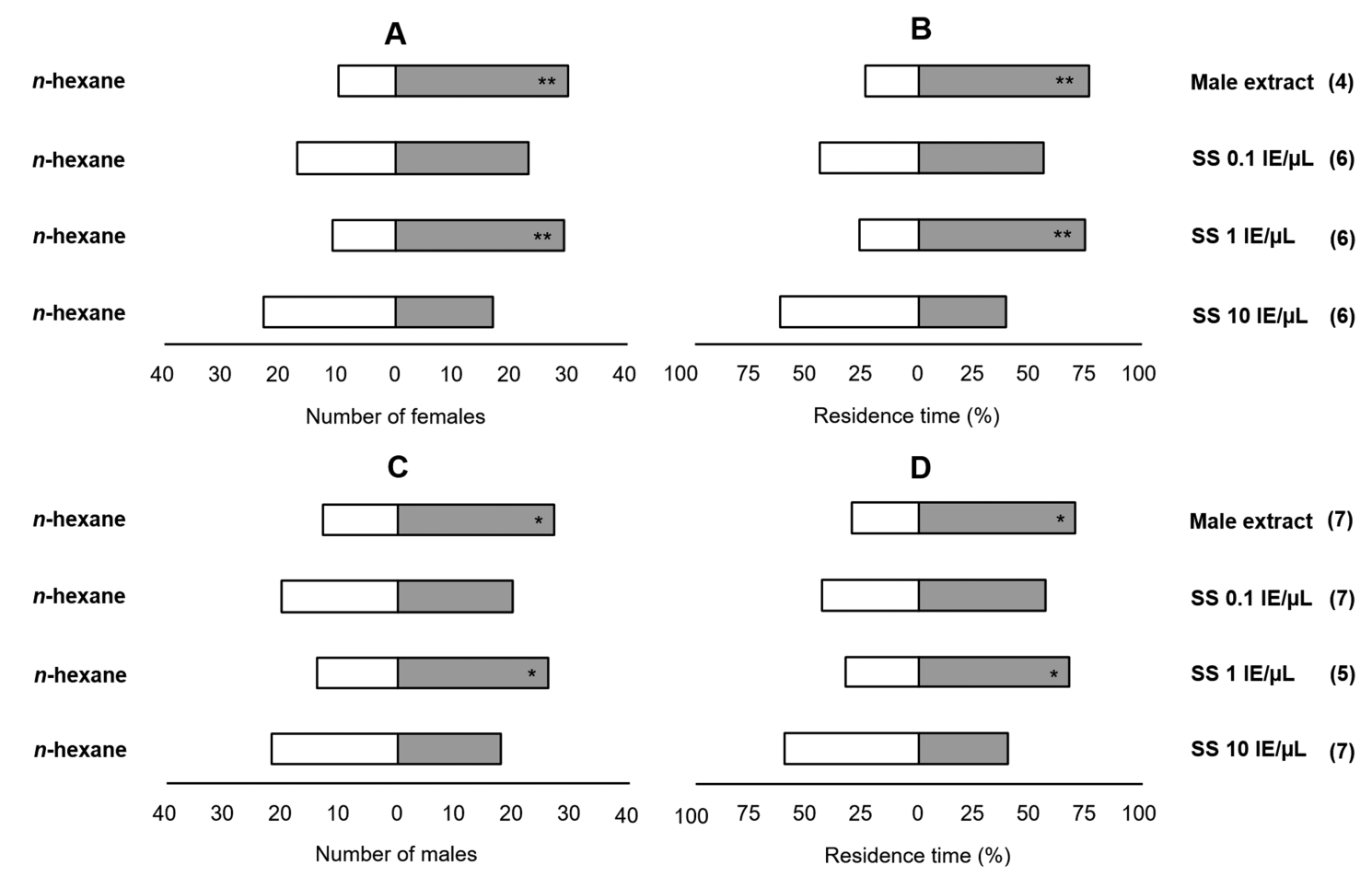

Figure 3. First choice and residence time of female (A, B) and male (C, D) Alphitobius diaperinus in Y-tube olfactometer bioassays in response to collected male volatile extracts at 1 insect equivalent (IE) $/ \mu \mathrm{L}$, and synthetic solutions (SS) containing all male-specific compounds $[(R)$-limonene, $(E)$-ocimene, 2-nonanone, $(S)$-linalool, $(R)$-daucene, and $(E, E)$ - $\alpha$-farnesene] at $0.1,1$, and $10 \mathrm{IE} / \mu \mathrm{L}$ against $n$-hexane as control. Analyses were carried out using chi-square test for first choice and Wilcoxon's matched-pairs test for residence time. Bars indicate the number of responsive insects and the residence time (\%) to each olfactometer arm. $*, P<0.05 ; * *, P<0.01$. Numbers in parentheses represent the number of insects that did not respond to the treatment tested.

Statistical Analysis. The choices made by the insects in the bioassays were analyzed by chi-square test, and the residence time was analyzed by Wilcoxon's matched-pairs test, by using the statistical program $\mathrm{R} 2.14 .0{ }^{35}$ with $95 \%$ of reliability.

\section{RESULTS}

Chemical Analyses. Chemical analysis of the headspace volatiles collected from both genders of $A$. diaperinus indicated that the males produced six volatile organic compounds that were not present in the volatile collections from females or from vermiculite and steel mesh (control) (Figure 1). GC-MS analysis of the male volatile extracts, comparison of the spectra with NIST, GC peak enhancement, and enantioselective GC with authentic standards confirmed the identity of the compounds to be $(R)$-limonene $(1),(E)$-ocimene (2), 2-nonanone (3), $(S)$ linalool (4), (R)-daucene (5) and (E,E)- $\alpha$-farnesene (6) (Table 1). 
Table 2. Statistical Analysis of the First Choice and Residence Time Data for Female and Male Alphitobius diaperinus in Y-Tube Olfactometer Bioassays with Different Synthetic Solutions, at 0.1, 1, or 10 Insect Equivalents (IE)/ $\mathrm{L}$, Containing Components of Male Aggregation Pheromone against $n$-Hexane (Control) ${ }^{a}$

\begin{tabular}{|c|c|c|c|c|c|}
\hline & \multirow[b]{2}{*}{$\begin{array}{l}\text { amount } \\
(\mathrm{IE} / \mu \mathrm{L})\end{array}$} & \multicolumn{2}{|c|}{ male response } & \multicolumn{2}{|c|}{ female response } \\
\hline & & first choice & residence time & first choice & residence time \\
\hline \multicolumn{6}{|l|}{ synthetic solution $(\mathrm{SS})$ composition } \\
\hline \multirow[t]{2}{*}{$(R)$-limonene, $(E)$-ocimene, 2-nonanone, $(S)$-linalool, $(R)$-daucene, $(E, E)$ - $\alpha$-farnesene } & 0.1 & $\chi^{2}=0.07$ & $\mathrm{~W}=250$ & $\chi^{2}=1.14$ & $\mathrm{~W}=251.5$ \\
\hline & & $P=0.79$ & $P=0.48$ & $P=0.28$ & $P=0.46$ \\
\hline \multirow{2}{*}{$(R)$-limonene, $(E)$-ocimene, 2-nonanone, $(S)$-linalool, $(R)$-daucene, $(E, E)$ - $\alpha$-farnesene } & 1 & $\chi^{2}=3.48$ & $\mathrm{~W}=689$ & $\chi^{2}=7.49$ & $\mathrm{~W}=688$ \\
\hline & & $P=0.03 *$ & $P<0.001 * * *$ & $P=0.003 * *$ & $P<0.001^{* * * *}$ \\
\hline \multirow[t]{2}{*}{$(R)$-limonene, $(E)$-ocimene, 2-nonanone, $(S)$-linalool, $(R)$-daucene, $(E, E)$ - $\alpha$-farnesene } & 10 & $\chi^{2}=0.29$ & $\mathrm{~W}=140$ & $\chi^{2}=1.14$ & $\mathrm{~W}=290$ \\
\hline & & $P=0.59$ & $P=0.66$ & $P=0.28$ & $P=0.12$ \\
\hline \multicolumn{6}{|l|}{ individual compounds } \\
\hline \multirow[t]{2}{*}{ (R)-limonene } & 1 & $\chi^{2}=0.28$ & $\mathrm{~W}=220.5$ & $\chi^{2}=0.06$ & $\mathrm{~W}=235$ \\
\hline & & $P=0.59$ & $P=0.95$ & $P=0.79$ & $P=0.71$ \\
\hline \multirow[t]{2}{*}{$(E)$-ocimene } & 1 & $\chi^{2}=0.78$ & $\mathrm{~W}=131$ & $\chi^{2}=0.08$ & $\mathrm{~W}=97$ \\
\hline & & $P=0.38$ & $P=0.83$ & $P=0.77$ & $P=0.13$ \\
\hline \multirow[t]{2}{*}{ 2-nonanone } & 1 & $\chi^{2}=0.08$ & $\mathrm{~W}=16$ & $\chi^{2}=3.00$ & $\mathrm{~W}=189$ \\
\hline & & $P=0.78$ & $P=0.90$ & $P=0.08$ & $P=0.48$ \\
\hline \multirow[t]{2}{*}{ (S)-linalool } & 1 & $\chi^{2}=2.57$ & $\mathrm{~W}=284.5$ & $\chi^{2}=4.57$ & $\mathrm{~W}=251.5$ \\
\hline & & $P=0.11$ & $P=0.15$ & $P=0.03^{*}$ & $P=0.46$ \\
\hline \multirow[t]{2}{*}{$(R)$-daucene } & 1 & $\chi^{2}=0.06$ & $W=328.5$ & $\chi^{2}=4.57$ & $W=282$ \\
\hline & & $P=0.79$ & $P=0.01^{* *}$ & $P=0.03^{*}$ & $P=0.16$ \\
\hline \multirow[t]{2}{*}{$(E, E)$ - $\alpha$-farnesene } & 1 & $\chi^{2}=3.33$ & $W=93$ & $\chi^{2}=1.20$ & $W=68$ \\
\hline & & $P=0.07$ & $P=0.06$ & $P=0.27$ & $P=0.65$ \\
\hline \multicolumn{6}{|l|}{ SS w/o one component } \\
\hline \multirow[t]{2}{*}{$\mathrm{SS}$ w/o $(R)$-limonene } & 1 & $\chi^{2}=1.80$ & $\mathrm{~W}=420$ & $\chi^{2}=0.20$ & $W=440$ \\
\hline & & $P=0.18$ & $P=0.68$ & $P=0.65$ & $P=0.68$ \\
\hline \multirow[t]{2}{*}{ SS w/o (E)-ocimene } & 1 & $\chi^{2}=3.20$ & $W=414$ & $\chi^{2}=1.80$ & $W=475$ \\
\hline & & $P=0.07$ & $P=0.96$ & $P=0.18$ & $P=0.24$ \\
\hline \multirow[t]{2}{*}{ SS w/o 2-nonanone } & 1 & $\chi^{2}=0.80$ & $\mathrm{~W}=352$ & $\chi^{2}=0.20$ & $W=496.5$ \\
\hline & & $P=0.37$ & $P=0.99$ & $P=0.65$ & $P=0.39$ \\
\hline \multirow[t]{2}{*}{ SS w/o (S)-linalool } & 1 & $\chi^{2}=1.80$ & $\mathrm{~W}=470.5$ & $\chi^{2}=0.20$ & $\mathrm{~W}=441.5$ \\
\hline & & $P=0.18$ & $P=0.42$ & $P=0.65$ & $P=0.30$ \\
\hline \multirow[t]{2}{*}{ SS w/o (R)-daucene } & 1 & $\chi^{2}=0.20$ & $\mathrm{~W}=431.5$ & $\chi^{2}=0.20$ & $W=422$ \\
\hline & & $P=0.65$ & $P=0.77$ & $P=0.65$ & $P=0.87$ \\
\hline \multirow[t]{2}{*}{$\mathrm{SS}$ w/o $(E, E)-\alpha$-farnesene } & 1 & $\chi^{2}=0.20$ & $W=447.5$ & $\chi^{2}=0.80$ & $W=461.5$ \\
\hline & & $P=0.65$ & $P=0.62$ & $P=0.37$ & $P=0.69$ \\
\hline \multicolumn{6}{|l|}{ SS with incorrect isomers } \\
\hline \multirow[t]{2}{*}{$(S)$-limonene, $(E)$-ocimene, 2-nonanone, $(S)$-linalool, $(R)$-daucene, $(E, E)$ - $\alpha$-farnesene } & 1 & $\chi^{2}=3.20$ & $\mathrm{~W}=131$ & $\chi^{2}=0.80$ & $\mathrm{~W}=102$ \\
\hline & & $P=0.07$ & $P=0.33$ & $P=0.37$ & $P=0.78$ \\
\hline \multirow[t]{2}{*}{$(R)$-limonene, $(Z)$-ocimene, 2-nonanone, $(S)$-linalool, $(R)$-daucene, $(E, E)$ - $\alpha$-farnesene } & 1 & $\chi^{2}=0.20$ & $\mathrm{~W}=142.5$ & $\chi^{2}=3.20$ & $\mathrm{~W}=99.5$ \\
\hline & & $P=0.65$ & $P=0.16$ & $P=0.07$ & $P=0.86$ \\
\hline$(R)$-limonene, $(E)$-ocimene, 2-nonanone, $(R)$-linalool, $(R)$-daucene, $(E, E)$ - $\alpha$-farnesene & 1 & $\chi^{2}=1.80$ & $\mathrm{~W}=112.5$ & $\chi^{2}=3.20$ & $\mathrm{~W}=106$ \\
\hline & & $P=0.18$ & $P=0.78$ & $P=0.07$ & $P=0.97$ \\
\hline$(R)$-limonene, $(E)$-ocimene, 2-nonanone, $(S)$-linalool, $(R)$-daucene, farnesene isomers & 1 & $\chi^{2}=3.20$ & $\mathrm{~W}=110.5$ & $\chi^{2}=1.80$ & $\mathrm{~W}=133$ \\
\hline & & $P=0.07$ & $P=0.84$ & $P=0.18$ & $P=0.29$ \\
\hline
\end{tabular}

${ }^{a}$ Analyses were carried out using chi-square test for first choice and Wilcoxon's matched-pairs test for residence time. $*, P<0.05 ; * *, P<0.01$; $* * *, P<0.001$.

The mean production of all six compounds was consistent across all samples analyzed $(N=60)$ (Table 1$)$.

Olfactometry Bioassays. Behavior bioassays using live A. diaperinus as the odor source showed that both genders were attracted to the odor from live adult males compared to air (control) (female, $\chi^{2}=12.80, P<0.001$; male, $\chi^{2}=9.80, P=$ 0.03 ) (Figure $2 \mathrm{~A}, \mathrm{C}$ ) and spent more time in the arm containing odor from live male adults (female, $W=705, P<0.001$; male, $W=681, P<0.001$ ) (Figure $2 \mathrm{~B}, \mathrm{D}$ ). The same behavior was observed when the odors of both live genders were compared to air [first choice (female, $\chi^{2}=9.81, P=0.002$; male, $\chi^{2}=9.72$,
$P=0.002$ ) (Figure 2A,C); residence time (female, $W=70$, $P<0.001$; male, $W=681, P<0.001$ )] (Figure 2B,D). When the odor from live females was evaluated, females were not attracted $\left(\chi^{2}=0.81, P=0.37, n=40\right)$ (Figure $2 \mathrm{~A}$ ), and males were attracted to air $\left(\chi^{2}=5.03, P=0.02, n=40\right)$ (Figure $2 \mathrm{C}$ ), whereas for the residence time, both females and males showed no preference between odor from live females and air (female, $W=421, P=0.85, n=40$; male $W=431, P=0.74, n=40$ ) (Figure 2B,D).

Both genders preferred odor from male volatile collections when compared to the control $n$-hexane (female, $\chi^{2}=9.05$, 


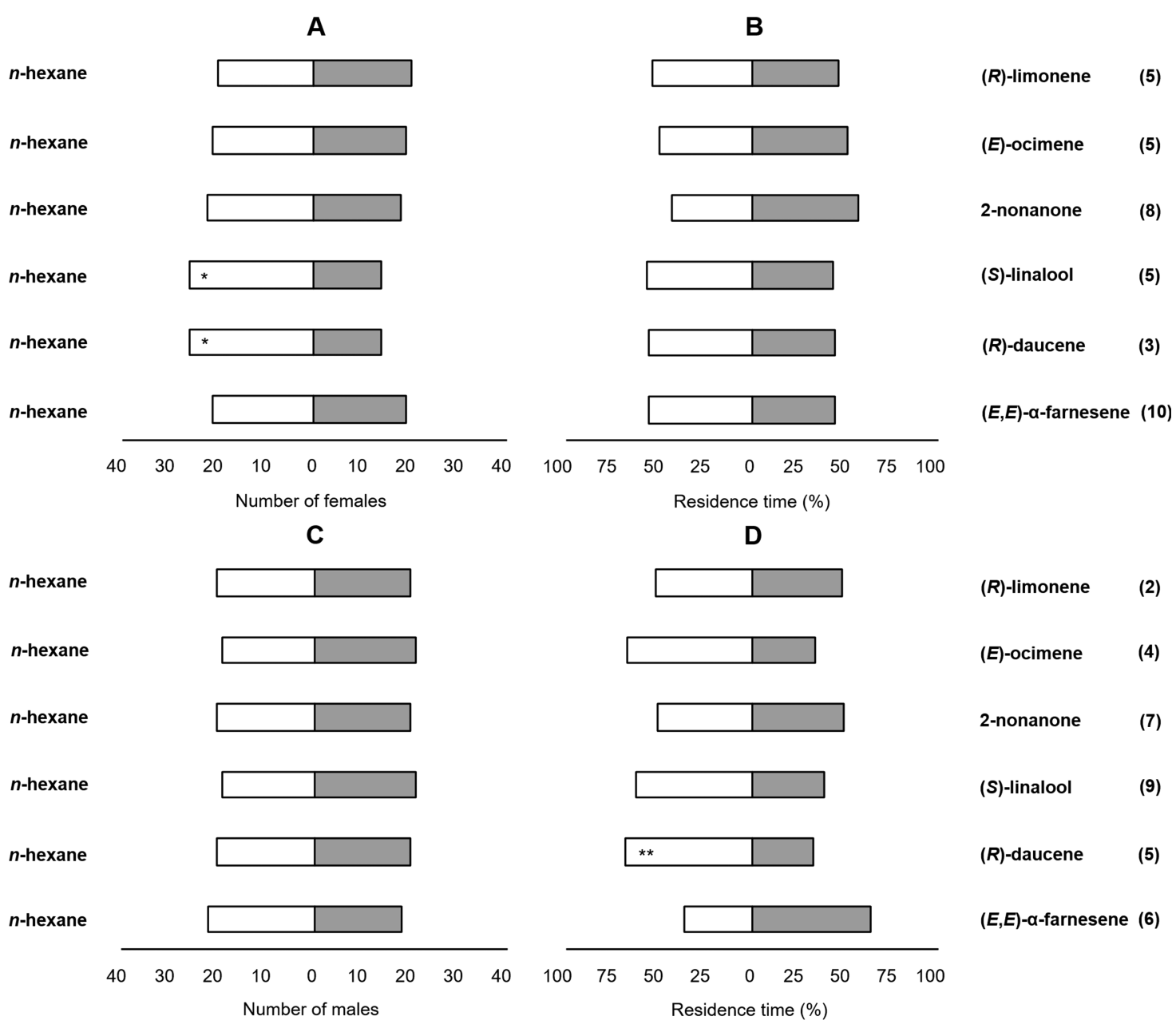

Figure 4. First choice and residence time of female (A, B) and male (C, D) Alphitobius diaperinus in Y-tube olfactometer bioassays in response to individual components of male-produced aggregation pheromone at 1 insect equivalent $(\mathrm{IE}) / \mu \mathrm{L}$ against $n$-hexane as control. Analyses were carried out using chi-square test for first choice and Wilcoxon's matched-pairs test for residence time. Bars indicate the number of responsive insects and the residence time (\%) to each olfactometer arm. $* *, P<0.01 ; *, P<0.05$. Numbers in parentheses represent the number of insects that did not respond to the treatment tested.

$P=0.003$; male, $\chi^{2}=4.68, P=0.03$ ) (Figure $3 \mathrm{~A}, \mathrm{C}$ ) and spent more time in the arm containing the odor from male volatile collections (female, $W=703.5, P<0.001$; male, $W=674$, $P<0.001$ ) (Figure 3B,D). Males and females were attracted to odor emitted from a synthetic solution containing all six malespecific components $[(R)$-limonene, $(E)$-ocimene, 2-nonanone, $(S)$-linalool, $(R)$-daucene, and $(E, E)-\alpha$-farnesene] in the same ratio produced by males and at concentration of $1 \mathrm{IE} / \mu \mathrm{L}$ compared to odor from hexane (Table 2; Figure 3A,C) and spent more time in the arm containing the odor from the synthetic solution (Table 2; Figure 3B,D). However, insects showed no preference for the synthetic solution when tested at 0.1 or $10 \mathrm{IE} / \mu \mathrm{L}$ (Table 2; Figure $3 \mathrm{~A}, \mathrm{C}$ ) over the solvent control $(P>0.05)$ and did not spend more time in the arm containing the odor from the synthetic solution $(P>0.05)$ (Table 2; Figure 3B,D). Usually when each male-specific compound was tested individually at $1 \mathrm{IE} / \mu \mathrm{L}$, males and females showed no significant behavior activity, except for $(S)$-linalool and $(R)$-daucene (Table 2; Figure 4). Males and females were not significantly attracted to synthetic pheromone blends with one component missing (Table 2; Figure 5) or when one of the six-component blends was incorporated as an incorrect isomer (Table 2; Figure 6).

\section{DISCUSSION}

Males of the Brazilian population of the lesser mealworm, A. diaperinus, have been shown to produce and emit six malespecific volatile compounds. Five of the six compounds identified were also described as components of the aggregation pheromone of this species in North America, ${ }^{15}$ that is, $(R)$-limonene, $(E)$-ocimene, 2-nonanone, $(S)$-linalool, and (R)-daucene. The sixth component identified in this study, $(E, E)-\alpha$-farnesene, is apparently exclusive to a Brazilian population. Y-bioassays confirmed the presence of a male-produced aggregation pheromone, with all six identified compounds required for pheromone activity. Furthermore, components need to be present in a similar ratio and concentration as emitted by male $A$. diaperinus to produce a positive chemotactic response in laboratory conditions. The bioassays conducted with odor from live females corroborated the chemical analysis, showing that live females do not produce the attractant that males produce to attract males and females and that their odor does not interfere with the male-produced aggregation pheromone. Males and females were not attracted to synthetic blends with concentration 10 times more or less compared to the amount produced naturally by males. A. diaperinus, as well as other Coleoptera species Phyllotreta cruciferae Goeze 


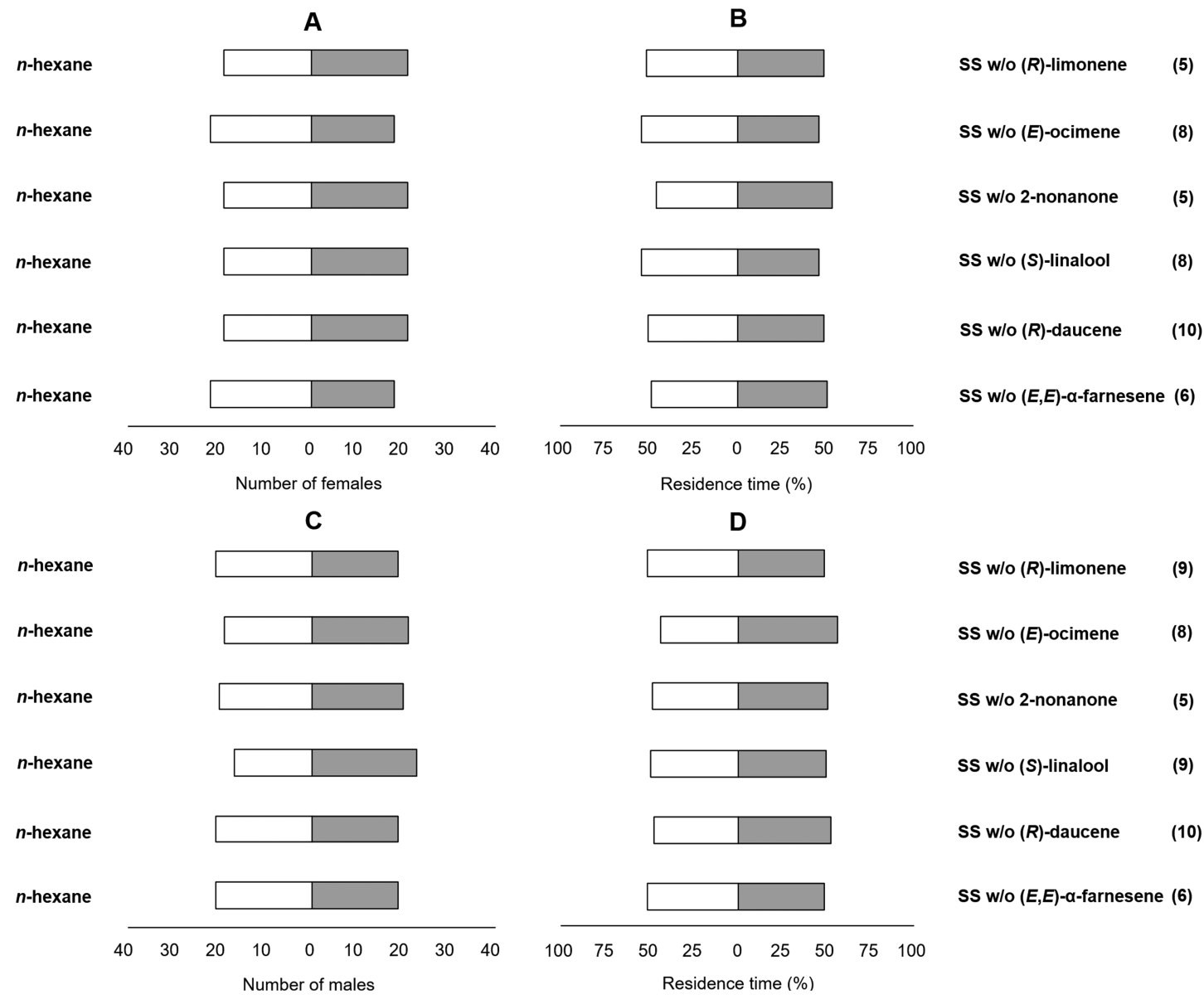

Figure 5. First choice and residence time of female (A, C) and male (B, D) Alphitobius diaperinus in Y-tube olfactometer bioassays in response to synthetic solutions (SS) of aggregation pheromone minus (w/o) a single component, at 1 insect equivalent (IE) $/ \mu \mathrm{L}$ against $n$-hexane as control. Analyses were carried out using chi-square test for first choice and Wilcoxon's matched-pairs test for residence time. Bars indicate the number of responsive insects and the residence time (\%) to each olfactometer arm. Numbers in parentheses represent the number of insects that did not respond to the treatment tested.

(Chrysomelidae $)^{36}$ and the boll weevil Anthonomus grandis Boheman (Curculionidae), ${ }^{37}$ did not show attraction to enantiomers of aggregation pheromone components. For pheromonemediated behavior in most species, and particularly by aggregation pheromones, a naturally occurring pheromone enantiomer is more attractive than the non-naturally occurring enantiomer. ${ }^{38}$ The effect of racemic blends differs between species. ${ }^{38}$ In some instances, the unnatural enantiomer does not interfere with the response to the active enantiomer, but in other species the presence of the enantiomer can reduce or eliminate the response. ${ }^{38}$ The stereochemistry of optically active pheromone components was elucidated in this work and matched those reported. ${ }^{15}(E, E)$ $\alpha$-Farnesene has been reported as an important semiochemical that acts as an attractant and kairomone for Coleoptera ${ }^{39,40}$ and Hymenoptera. ${ }^{41}$ This compound is also present in pheromone blends of Diptera, Hemiptera, Hymenoptera, Isoptera, and Lepidoptera, ${ }^{42-48}$ and here we report the first instance of its appearance as an aggregation pheromone component for a member of the Coleoptera.

In addition to the composition difference, the ratio between the components produced by males from the Brazilian population was different from that of the North American population; that is, for the Brazilian population the major component was $(S)$-linalool, whereas for the North American population, the major component was $(E)$-ocimene. Wind tunnel bioassays showed that only three components of the $A$. diaperinus aggregation pheromone are necessary to attract both genders of North American populations, ${ }^{17}$ whereas our results showed that Brazilian populations need all six male-specific compounds for pheromone-mediated behavior.

Differences in pheromonal blend might be due to geographical isolation. For Coleoptera this phenomenon was reported for pine bark beetles, Ips pini Say (Scolytidae), where 11 years after the first pheromone identification, a new component was isolated from another population. ${ }^{19,20,49,50}$ For Hawaiian and Australian populations of cane weevil borers, Rhabdoscelus obscurus Boisduval ${ }^{22,51}$ and also for bark beetles, Ips subelongatus Motschulsky, population divergence in aggregation pheromone responses was reported. ${ }^{24}$ This phenomenon is not exclusive to Coleoptera. Differences between populations also occur, for example, in the sex pheromone of the European corn borer, Ostrinia nubilalis Hübner (Lepidoptera: Pyralidae) ${ }^{21}$ and a trail pheromone present in stingless bees, Trigona corvina Cockerell (Hymenoptera: Apidae). ${ }^{23}$

In the United States, the pheromonal blend of North American $A$. diaperinus showed promising results in trapping experiments in poultry houses, with pheromone traps attracting 3 times more adults and larvae than control traps. ${ }^{15,16}$ Our results suggest that if the North American pheromone blend were used in Brazil, the mixture would probably not be effective 

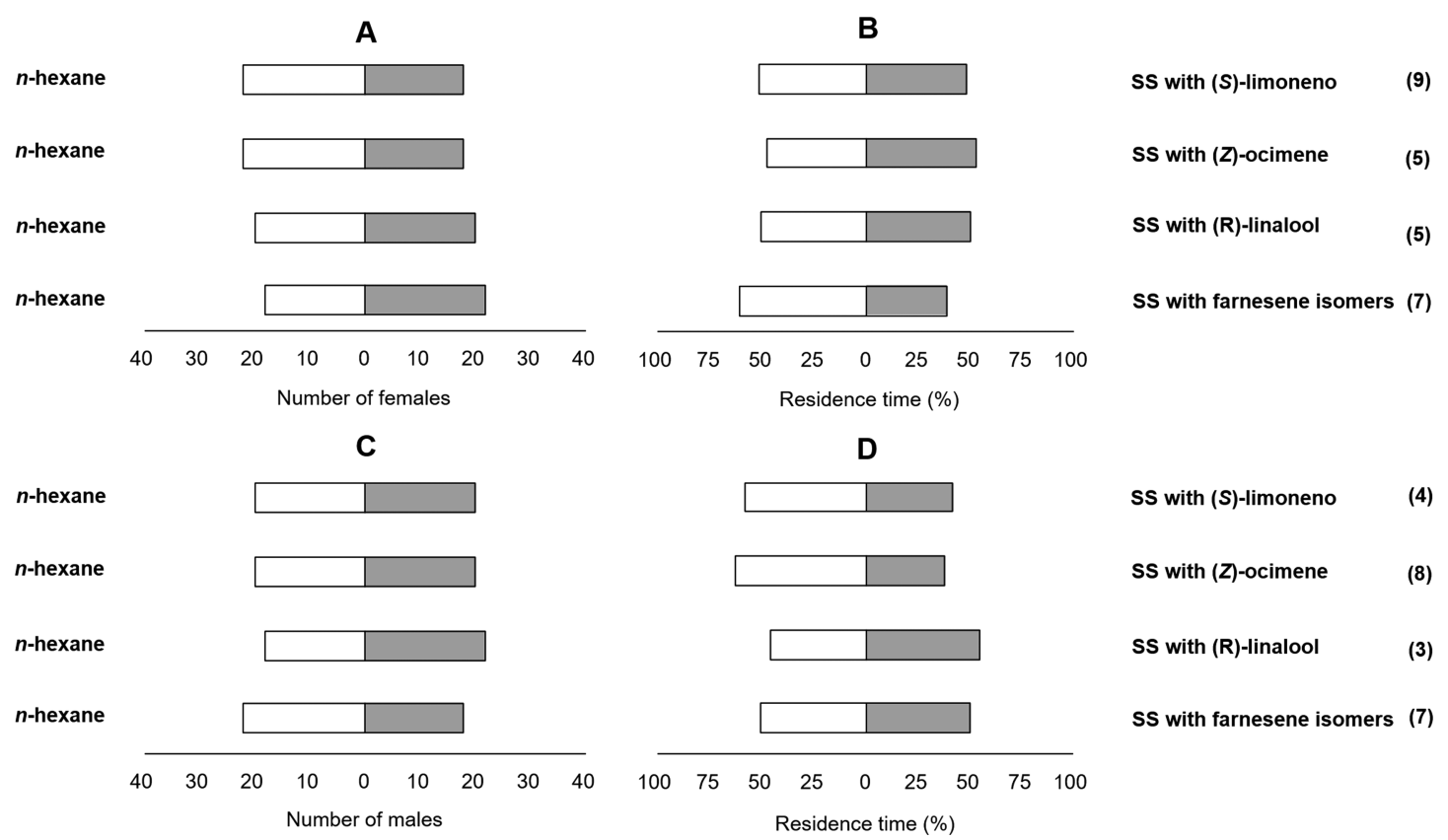

Figure 6. First choice and residence time of female (A, B) and male (C, D) Alphitobius diaperinus in Y-tube olfactometer bioassays in response to synthetic solutions (SS) of aggregation pheromone, prepared with one component present as an incorrect isomer, at 1 insect equivalent (IE) $/ \mu \mathrm{L}$ against $n$-hexane as control. Analyses were carried out using chi-square test for first choice and Wilcoxon's matched-pairs test for residence time. Bars indicate the number of responsive insects and the residence time (\%) to each olfactometer arm. Numbers in parentheses represent the number of insects that did not respond to the treatment tested.

for A. diaperinus management. Problems with deployment of sex pheromones for control of insect pests across different geographical regions have been reported elsewhere. For fall armyworm, Spodoptera frugiperda Smith (Lepidoptera: Noctuidae), interpopulational differences in sex pheromone components between sympatric regions present difficulties in the application of this technology. ${ }^{52,33}$ Thus, for control of Brazilian populations, careful consideration for use of the six component blend must be applied, whereas for other populations outside North America and Brazil, pheromone composition must be verified prior to deployment in trapping systems.

One of the major problems in poultry production in Brazil is keeping poultry litter free of $A$. diaperinus. Because extensive chemical control is unaffordable and often involves replacement of poultry litter, sustainable and less expensive methods to control and manage $A$. diaperinus populations in poultry houses would have an enormous and positive impact in Brazil. Further studies are required to investigate the pheromone composition in different populations of $A$. diaperinus around the world to provide control of this cosmopolitan pest. For Brazilian populations, the next step is to test the feasibility of using pheromone-based traps in poultry houses and to quantify the economic and social impact of reduced chemical control upon poultry production.

\section{ASSOCIATED CONTENT}

S Supporting Information

The Supporting Information is available free of charge on the ACS Publications website at DOI: 10.1021/acs.jafc.6b02235.

Figures S1-S8 (PDF)

\section{AUTHOR INFORMATION}

\section{Corresponding Author}

*(M.C.B.-M.) Phone: +55 61 3448-4932. Fax: +55 61 3448-4762.

E-mail: carolina.blassioli@embrapa.br.

\section{Funding}

This work received financial support from the Coordination of Superior Level Staff Improving (CAPES) through a grant to M.J.H. and from the National Council for Scientific and Technological Development $(\mathrm{CNPq})$, the Brazilian Corporation of Agricultural Research (EMBRAPA), and the Research Support Foundation of the Federal District (FAP-DF). Rothamsted research receives grant-aided support from the biotechnology and Biological Sciences Research Council (BBSRC) of the United Kingdom.

\section{Notes}

The authors declare no competing financial interest.

\section{ACKNOWLEDGMENTS}

We express special thanks to Anildo Cunha, Jr., and Gerson Neudi Scheuermann for providing information about A. diaperinus. We thank the Fitotecnia Post-Graduate Program of the Federal University of Rio Grande do Sul for the use of their facility.

\section{REFERENCES}

(1) Axtell, R. C.; Arends, J. J. Ecology and management of arthropod pests of poultry. Annu. Rev. Entomol. 1990, 35, 101-126.

(2) Dunford, J. C.; Kaufman, P. E. Lesser Mealworm, Litter Beetle, Alphitobius diaperinus (Panzer) (Insecta: Coleoptera: Tenebrionidae); University of Florida IFAS, 2006; http://edis.ifas.ufl.edu/pdffiles/IN/ IN66200.pdf (accessed Jan 8, 2016) .

(3) Japp, A. K.; Bicho, C. L.; Silva, A. V. F. Importância e medidas de controle para Alphitobius diaperinus em aviários. Cienc. Rural 2010, 40, $1668-1673$.

(4) Salin, C.; Delettre, Y. R.; Cannavacciuolo, M.; Vernon, P. Spatial distribution of Alphitobius diaperinus (Panzer) (Coleoptera: Tenebrionidae) in the soil of a poultry house along a breeding cycle. Eur. J. Soil Biol. 2000, 36, 107-115.

(5) Lambkin, T. A.; Kopittke, R. A.; Rice, S. J.; Bartlett, J. S.; Zalucki, M. P. Distributions of lesser mealworm (Coleoptera: Tenebrionidae) 
in litter of a compacted earth-floor broiler house in subtropical Queensland, Australia. J. Econ. Entomol. 2007, 100, 1136-1146.

(6) Lambkin, T. A.; Kopittke, R. A.; Rice, S. J.; Bartlett, J. S.; Zalucki, M. P. Factors affecting localized abundance and distribution of lesser mealworm in earth-floor broiler houses in subtropical Australia. J. Econ. Entomol. 2008, 101, 61-67.

(7) McAllister, J. C.; Steelman, C. D.; Newberry, L. A.; Skeeles, J. K. Isolation of infectious bursal disease virus from the lesser mealworm, Alphitobius diaperinus (Panzer). Poult. Sci. 1995, 74, 45-49.

(8) Goodwin, M. A.; Waltman, W. D. Transmission of eimeria, viruses and bacteria to chicks: darkling beetles (Alphitobius diaperinus) as vectors of pathogens. J. Appl. Poult. Res. 1996, 5, 51-55.

(9) Hazeleger, W. C.; Bolder, M. N.; Beumer, R. R.; Jacobs-Reitsma, W. F. Darkling beetles (Alphitobius diaperinus) and their larvae as potential vectors for the transfer of Campylobacter jejuni and Salmonella enterica serovar paratyphi B variant Java between successive broiler flocks. Appl. Environ. Microbiol. 2008, 74, 6887-6891.

(10) Roche, A. J.; Cox, N. A.; Richardson, L. J.; Buhr, R. J.; Cason, J. A.; Fairchild, B. D.; Hinkle, N. C. Transmission of Salmonella to broilers by contaminated larval and adult lesser mealworms, Alphitobius diaperinus (Coleoptera: Tenebrionidae). Poult. Sci. 2009, $88,44-48$

(11) Leffer, A. M.; Kuttel, J.; Martins, L. M.; Pedroso, A. C.; AstolfiFerreira, C. S.; Ferreira, F.; Ferreira, A. J. P. Vectorial competence of larvae and adults of Alphitobius diaperinus in the transmission of Salmonella enteritidis in poultry. Vector-Borne Zoonotic Dis. 2010, 10, 481-487.

(12) Chernaki-Leffer, A. M.; Sosa-Gòmez, D. R.; Almeida, L. M. Selection for entomopathogenic fungi and LD50 of Metarhizium anisopliae (Metsch.) Sorok. for the lesser mealworm Alphitobius diaperinus (Panzer) (Coleoptera: Tenebrionidae). Braz. J. Poultry Sci. 2007, 9, 187-191.

(13) Pezowicz, E.; Mazurkiewicz, A.; Tumialis, D. Sensitivity of imago and larvae of the lesser mealworm Alphitobius diaperinus (Panzer 1797) in a sawdust litter to selected species and strains of Steinernematidae and Heterorhabditidae under laboratory conditions. Anim. Sci. 2013, 52, 161-166.

(14) Prado, G. P.; Stefani, L. M.; Silva, A. S.; Smaniotto, L. F.; Garcia, F. R. M.; Moura, N. F. Alphitobius diaperinus (Coleoptera: Tenebrionidae) susceptibility to Cunila angustifolia essential oil. J. Med. Entomol. 2013, 50, 1040-1045.

(15) Bartelt, R. J.; Zilkowski, B. W.; Cossé, A. A.; Steelman, C. D.; Singh, N. Male-produced aggregation pheromone of the lesser mealworm beetle. J. Chem. Ecol. 2009, 35, 422-434.

(16) Singh, N.; Johnson, D. T. Attractiveness of an aggregation pheromone lure and chicken droppings to adults and larvae of Alphitobius diaperinus (Coleoptera: Tenebrionidae). J. Econ. Entomol. 2012, 105, 2196-2206.

(17) Cossé, A. A.; Zilcowski, B. W. Behavioural responses of lesser mealworm beetles, Alphitobius diaperinus, (Coleoptera: Tenebrionidae) to pheromone components using a wind tunnel dual choice walking bioassay. J. Insect Behav. 2015, 28, 202-210.

(18) Hassemer, M. J.; Sant'Ana, J.; de Oliveira, M. W.; Borges, M.; Laumann, R. A.; Caumo, M.; Blassioli-Moraes, M. C. Chemical composition of Alphitobius diaperinus (Coleoptera: Tenebrionidae) abdominal glands and the influence of 1,4-benzoquinones on its behavior. J. Econ. Entomol. 2015, 108, 2107-2116.

(19) Lanier, G. N.; Claesson, A.; Stewart, T.; Piston, J.; Silverstein, R. M. Ips pini: the basis for interpopulational differences in pheromone biology. J. Chem. Ecol. 1980, 6, 677-687.

(20) Teale, S. A.; Webster, F. X.; Zhang, A.; Lancer, G. N. Lanierone: a new pheromone component from lps pini (Coleoptera: Scolytidae) in New York. J. Chem. Ecol. 1991, 17, 1159-1176.

(21) Dopman, E. B.; Bogdanowicz, S. M.; Harrison, R. G. Genetic mapping of sexual isolation between $\mathrm{E}$ and $\mathrm{Z}$ pheromone strains of the European corn borer (Ostrinia nubilalis). Genetics 2004, 167, 301-309.

(22) Muniappan, R.; Bamba, J.; Cruz, J.; Reddy, G. V. P. Field response of Guam populations of the New Guinea sugarcane weevil, Rhabdoscelus obscurus (boisduval) (Coleoptera: Curculionidae), to aggregation pheromones and food volatiles. Micronesica 2004, 37, 5768.

(23) Jarau, S.; Dambacher, J.; Twele, R.; Aguilar, I.; Francke, W.; Ayasse, M. The trail pheromone of a stingless bee, Trigona corvina (Hymenoptera, Apidae, Meliponini), varies between populations. Chem. Senses 2010, 35, 593-601.

(24) Chen, D.; Li, L.; Zhang, Q.; Zhang, S.; Wang, H.; Zhang, Z.; Zhao, L.; Kong, X. Population divergence of aggregation pheromone responses in Ips subelongatus in northeastern China. Insect Sci. 2015, 00, 1744-7917.

(25) Spicer, J. A.; Brimble, M. A.; Rowan, D. D. Oxidation of $\alpha$ farnesene. Aust. J. Chem. 1993, 46, 1929-1940.

(26) Sýkora, V.; Novotný, L.; Holub, M.; Herout, V.; Šorm, F. On terpenes. CXVII. The proof of structure of carotol and daucol. Collect. Czech. Chem. Commun. 1961, 26, 788-802.

(27) Levisalles, J.; Rudler, H.; Terpénoides, II; Carotol, I. Stéreochimedu carotol. Bull. Soc. Chim. Fr. 1967, 365, 2059-2066.

(28) Bennett, N. B.; Stoltz, B. M. A unified approach to the daucane and sphenolobane bicyclo[5.3.0]decane core: enantioselective total syntheses of daucene, daucenal, epoxydaucenal B, and 14-panisoyloxydauc-4,8-diene. Chem.-Eur. J. 2013, 19, 17745-17750.

(29) Rice, S. J.; Lambkin, T. A. A new culture method for the lesser mealworm. J. Appl. Entomol. 2009, 133, 67-72.

(30) Esquivel, J. F.; Crippen, T. L.; Ward, L. A. Improved visualization of Alphitobius diaperinus (Panzer) (Coleoptera: Tenebrionidae) - part I: morphological features for sex determination of multiple stadia. Psyche: J. Entomol. 2012, 2012, 1-7.

(31) Moraes, M. C.; Millar, J. G.; Laumann, R. A.; Sujii, E. R.; Pires, C. S.; Borges, M. Sex attractant pheromone from the neotropical redshouldered stink bug, Thyanta perditor (F.). J. Chem. Ecol. 2005, 31, $1415-1427$.

(32) Borges, M.; Millar, J. G.; Laumann, R. A.; Moraes, M. C. B. A male-produced sex pheromone from the neotropical redbanded stink bug, Piezodorus guildinii (W.). J. Chem. Ecol. 2007, 33, 1235-1248.

(33) NIST. Chemistry WebBook, http://webbook.nist.gov/chemistry/ , 2011

(34) Pherobase. Database of pheromone and other semiochemicals, http://www.pherobase.com/database/kovats/kovats-index.php (accessed Jan 19, 2016).

(35) R Development Core Team. R: A Language and Environment for Statistical Computing; R Foundation for Statistical Computing, Vienna, Austria, 2011.

(36) Tóth, M.; Csonka, E.; Bartelt, R. J.; Cossé, A. A.; Zilkowski, B. W.; Muto, S.; Mori, K. Pheromonal activity of compounds identified from male Phyllotreta cruciferae: field tests of racemic mixtures, pure enantiomers, and combinations with allyl isothiocyanate. J. Chem. Ecol. 2005, 31, 2705-2720.

(37) Dickens, J. C.; Mori, K. Receptor chirality and behavioural specificity of the boll weevil, Anthonomus grandis Boh. (Coleoptera: Curculionidae), for its pheromone, (+)-grandisol. J. Chem. Ecol. 1989, $15,517-528$.

(38) Mori, K. Significance of chirality in pheromone science. Bioorg. Med. Chem. 2007, 15, 7505-7523.

(39) Sun, X. L.; Wang, G. C.; Cai, X. M.; Jin, S.; Gao, Y.; Chen, Z. M. The tea weevil, Myllocerinus aurolineatus, is attracted to volatiles induced by conspecifics. J. Chem. Ecol. 2010, 36, 388-395.

(40) Yasui, H.; Akino, T.; Fukaya, M.; Wakamura, S.; Ono, H. Sesquiterpene hydrocarbons: kairomones with a releaser effect in the sexual communication of the white-spotted longicorn beetle, Anoplophora malasiaca (Thomson) (Coleoptera: Cerambycidae). Chemoecology 2008, 18, 233-242.

(41) Michereff, M. F.; Laumann, R. A.; Borges, M.; Michereff-Filho, M.; Diniz, I. R.; Neto, A. L.; Moraes, M. C. Volatiles mediating a plantherbivore-natural enemy interaction in resistant and susceptible soybean cultivars. J. Chem. Ecol. 2011, 37, 273-285.

(42) Heath, R. R.; Landolt, P. J.; Tumlinson, J. H.; Chambers, D. L.; Murphy, R. E.; Doolittle, R. E.; Dueben, B. D.; Sivinski, J.; Calkins, C. O. Analysis, synthesis, formulation, and field testing of three major 
components of male Mediterranean fruit fly pheromone. J. Chem. Ecol. 1991, 17, 1925-1940.

(43) Nault, L. R.; Bowers, W. S. Multiple alarm pheromones in aphids. Entomol. Exp. Appl. 1974, 17, 455-457.

(44) Aldrich, J. R.; Waite, G. K.; Moore, C.; Payne, J. A.; Lusby, W. R.; Kochansky, J. P. Male-specific volatiles from Nearctic and Australasian true bugs (Heteroptera: Coreidae and Alydidae). J. Chem. Ecol. 1993, 19, 2767-2781.

(45) Khrimian, A.; Fay, H. A. C.; Guzman, F.; Chauhan, K.; Moore, C.; Aldrich, J. R. Pheromone of the banana-spotting bug, Amblypelta lutescens lutescens distant (Heteroptera: Coreidae): identification, synthesis, and field bioassay. Psyche 2012, 2012, 1-8.

(46) Cane, J. H. Chemical evolution and chemosystematics of the Dufonr's gland secretions of the lactone-producing bees (Hymenoptera: Colletidae, Halictidae, and Oxaeidae). Evolution 1983, 37, 657674.

(47) Schulz, S.; Boppre, M.; Vane-Wright, R. I. Specific mixtures of secretions from male scent organs of African milkweed butterflies (Danainae). Philos. Trans. R. Soc., B 1993, 342, 161-181.

(48) Šobotník, J.; Hanus, R.; Kalinová, B.; Piskorski, R.; Cvacka, J.; Bourguignon, T.; Roisin, Y. (E,E)- $\alpha$-Farnesene, an alarm pheromone of the termite Prorhinotermes canalifrons. J. Chem. Ecol. 2008, 34, 478486.

(49) Symonds, M. R. E.; Elgar, M. A. The mode of pheromone evolution: evidence from bark beetles. Proc. R. Soc. London, Ser. B 2004, 271, 839-846.

(50) Miller, D. R.; Borden, J. H.; Slessor, K. N. Inter- and intrapopulation variation of the pheromone, ipsdienol produced by male pine engravers, Ips pini (Say) (Coleoptera: Scolytidae). J. Chem. Ecol. 1989, 15, 233-247.

(51) Giblin-Davis, R. M.; Gries, R.; Crespi, B.; Robertson, L. N.; Hara, A. H.; Gries, G.; O’Brien, C. W.; Pierce, H. D., Jr. Aggregation pheromones of two geographical isolates of the New Guinea sugarcane weevil Rhabdoscelus obscurus. J. Chem. Ecol. 2000, 26, 2763-2780.

(52) Andrade, R.; Rodriguez, C.; Oehlschlager, A. C. Optimization of a pheromone lure for Spodoptera frugiperda (Smith) in Central America. J. Braz. Chem. Soc. 2000, 11, 609-613.

(53) Batista-Pereira, L. G.; Stein, K.; de Paula, A. F.; Moreira, J. A.; Cruz, I.; Figueiredo, M. L. L.; Perri, J.; Corrêa, A. Isolation, identification, synthesis, and field evaluation of the sex pheromone of the Brazilian population of Spodoptera frugiperda. J. Chem. Ecol. 2006, 32, 1085-1099. 